\title{
Requirements of Applying Evidence-Based Practice of Social Work in Secondary Schools
}

\section{Hamdy A bdallah A bdelaal (Ph.D.)} Associate Professor, Department of Social Work Fields High Institute of Social Work, Qena 


\section{Abstract}

This study aims to identify the requirements of applying evidence-based practice (EBP) of social work in secondary schools. The sample includes (348) school social workers who were randomly assigned. The study concludes that the concept of EBP is not clear to social workers working in secondary schools. It also demonstrates that the most important requirements of EBP of social work in secondary schools, in order of importance, are knowledge requirements, skill requirements and ethical requirements. Finally, the study determines the barriers of applying EBP of social work in secondary schools.

Keywords: evidence-based practice; school social work; social workers; secondary schools; requirements.

\section{Introduction}

The evidence-based practice (EBP) is a term that originated in medicine aiming for the practice of evidence-based medicine. A clinician should be able to integrate the best research evidence with clinical expertise and patient values. This approach to client care has shifted into mental health and more recently into education (Cynthia \& Laura, 2004, P. 67).

In addition, EBP is founded on results from research and welldocumented studies, which determine ways of working and the interventions given (Sohlberg \& Sohlberg, 2013, p. 168). Work is thus not based on the professional's own limited experience. Evidencebased knowledge can, in some ways, be described as opposite to practice knowledge. Rather, EBP is an approach to practice that incorporates evidence and research throughout the engagement, assessment, intervention, and evaluation processes with clients (Eliasson, 2014, p. 25).

The concept of EBP has spread and moved to other professions, such as pharmacy, psychiatry, and social work (El-Nagem, 2009, p.295). It now stands as the signature approach to prevention and intervention throughout social and behavioral sciences and in educational settings. According to the Social Work Policy Institute, EBP is a process in which the practitioner combines well-researched interventions with clinical experience and ethics, and client preferences and culture to guide and inform the delivery of treatments and services (Teasley, 2016, p. 5).

Furthermore, EBP is a process which includes critical thinking and evaluation of information to define the most effective and efficient treatment for client or community. It is a three-pronged 
approach, taking into consideration, the social worker's individual expertise, the client's values and expectations, the best evidence (Nichols, 2018).

Gibbs (2003) defined EBP as follows: "placing the client's benefits first, evidence-based social workers adopt a process of lifelong learning that includes continually posing definite questions of direct practical importance to clients, searching objectively and efficiently for the current best evidence related to each question, and taking suitable action guided by evidence"(p. 6).

In social work, researchers agree that EBP is a process including creating an answerable question based on a client need, locating the best available evidence to answer the question, evaluating the quality of the evidence as well as its applicability, applying the evidence, and evaluating the effectiveness and efficiency of the solution (EvidenceBased Practice, 2018).

In spite of the multidisciplinary recommendations to use evidence-based interventions in schools and the growing knowledge base of such practices, most school-based practitioners are not using empirically supported interventions. On the basis of a careful analysis of barriers to the implementation of the best researched programs, an online free, and publicly available database of best practices has been created to facilitate their use in schools. The database provides detailed information about evidence-based programs, promising practices, and resources for social workers, teachers, and other school staff to address student needs across multiple domains (Powers et al., 2011, p. 120).

Despite the various studies conducted on EBP in social work in America and Europe, the scope of its use in school social work settings in Egypt is still low (Helal, 2017). There is a need for more research concerning EBP application within that context, with a particular focus on identifying requirements of its application in Egyptian secondary schools (Zedan, et al, 2016, p. 57). Therefore, this study was conducted with the aim to fill that apparent gap and to investigate the requirements of applying evidence-based practice of social work in secondary schools. The final findings of this study may support development of EBPs in school social work settings in Egypt.

\section{Study Objectives:}

The main objective of the present study is to identify the requirements of applying evidence-based practice of social work in secondary schools. 


\section{Study Questions:}

The study is an attempt to answer these questions: To what extent is the concept of EBP clear for secondary schools' social workers? What are the requirements of applying EBP of social work in secondary schools? What are the barriers that prevent applying of EBP of social work in secondary schools?

\section{Literature Review}

EBP is one of the scientific trends in the school social work field, which aims at reducing the gap and linking scientific research to professional practice. In the light of this scientific trend in the USA, such practice should be reflected in the school social work field in Egypt (Saad, 2014, p.135). Besides, one of the ideas on which the concept of EBP is based is that professional practitioners can reach the outcome of the accumulation of highly effective professional practices that can be disseminated and used by others (Bahjat, 2015, p. 196).

Generally, the EBP can be employed in all levels; (Macro, Mezzo and Micro), through the professional practices of social work (assessment, intervention, and evaluation), and with all clients (Khalil \& Farhan, 2014, p. 34).

Howard \& Jenson (2013) discuss the five essential steps of EBP: step 1: converting practice information needs into answerable questions; step 2: locating evidence to answer questions; steps 3 and 4: appraising and applying evidence to practice and policy decisions; step 5: evaluating the process. The complexity involved in steps one to four demands an ongoing evaluation of one's knowledge of current literature, familiarity with constantly changing electronic databases, and skills in drawing conclusions based on methodological rigor ( $\mathrm{p}$. 284).

Moreover, Thyer (2006) defines five steps that are important when working according to EBP: (1) convert one's need for information into an answerable question; (2) track down the best evidence to answer that question; (3) critically appraise that evidence in terms of its validity, significance, and usefulness; (4) integrate this critical appraisal of research evidence with one's expertise and their values and circumstances and (5) evaluate one's effectiveness in undertaking the four previous steps (p. 36).

Additionally, Reid (2018) mentions that there is a series of steps a school social worker can follow when implementing EBP. The first one is to ask questions: upon meeting with the client/s, it is important to interview the client in order to assess the situation and determine 
the need to be met. This is the basis for determining what intervention would be required. The second step is to gather information: based on the need determined, there may be a series of interventions most appropriate. This is where gathering information through research helps build evidence in support of the best intervention to use. Gathering information can involve resources ranging from science articles to current studies and peer- reviewed literature. The last step is to choose or refuse evidence: taking appropriate action guided by evidence (p. 131).

The steps in EBP appear deceptively simple at first glance. However, the process of EBP requires knowledge of current literature about the onset, prevention, and treatment of client or social problems, the ability to search for relevant information and data, and skills to evaluate and apply knowledge obtained in systematic searches (Howard \& Jenson, 2013, p. 285).

Barret et al, (2008) identify indicators of EBP in school social work settings are:

a) Connections between school social work practice and the knowledge base for practice are clearly articulated.

b) The school social worker regularly updates knowledge and skills for practice through a range of professional development activities such as systematic reading of the research literature and the attendance of conferences, seminars and workshops (p. 370).

School social work takes place within the dynamic context of the educational landscape. However, research suggests that school social work practice has been slow to adjust to the demands of EBP. Little research has assessed whether school social workers are being adequately prepared to deal with the educational shifts that underlie today's practice (Berzin, \& O'Connor, 2010, p. 239). Albrithen (2010) describes EBP as a crucial turning point or a breakthrough to reform the course of the professional practice of social work (p. 123).

Further, EBP limits the gap between theory and practice. Thus, it is necessary for all social work practitioners adopt this type of practice for more effective professional practice when working with clients (Zedan, et al, 2016, p. 58).

The concept of EBP has become one of the most widely understood concepts of western social work literature today. Special scientific journals have been assigned to publish studies related to the provision of the knowledge base and the scientific articles that attempt to clarify the concept of EBP and connect it to issues and Fields of the multiple practice (Helal, 2017). 


\section{EBP in School Social Work Settings in Egypt}

School social work settings in Egypt are an organized professional effort to foster the social growth of students in order to create the most appropriate conditions for their growth according to their preferences and in accordance with the conditions and needs of the Egyptian society (Hapeep \& Hana, 2011, p. 212). It is carried out by social workers trained scientifically and practically to work in the school field, and rely on the knowledge, theories, philosophy and values of social work in helping students to take advantage of the resources of the school and help them to address their problems and engage in school life for the success of the school's function. (kamar \& Mabrook, 2012, p. 232)

According to Tawfiq (1986), school social work in Egypt aims to:

a) Develop some manual, technical and intellectual skills for students;

b) Assist student to have adequate information and knowledge to help them understand themselves and their community;

c), help students acquire a range of good attitudes, including faith in God and His messengers and respect for religious values that promote belonging to the local, national and human community, faith in common goals, ability to drive and dependency, ability to take responsibility, respect for the system, value of time and work, realistic thinking and ability to solve problems (p. 43)

Despite the emergence of modern trends in the practice of social work, the application of school social work in Egypt is still based on traditional practice (social casework, social group work, community organization). There may be some attempts to focus on EBP in this field through conducting studies and scientific research by master and $\mathrm{PhD}$ researchers in Egyptian universities. El-Nagem (2009) recommends the need to expand scientific writing and publishing on EBP, to reconsider the practice of social work, and to enable practitioners to apply EBP strategy. Saad's study (2014) concludes that there is a good level of readiness from the faculty staff to adopt teaching EBP in order to overcome and deal with all the challenges facing teaching EBP of social work. Helal (2017) notes that there are three main components for preparing a school social worker to apply EBP: a) the study of constituent courses such as social, humanitarian, economic, and cultural sciences; b) the study of professional courses associated with methods and technical tools of school social work in various settings; and c) field practicum within schools. 
Suleiman and Yusuf's study (2020) identify the requirements of using the practice based on evidence as one of the contemporary trends in developing the professional practice of community organization method by identifying knowledge requirements skills, values, and training. According to Helal (2013), there are four main barriers facing practitioners when applying EBP of social work in Egypt: barriers due to social work education institutions; barriers due to lack of evidence databases; barriers due to professional practice institutions (schools); and barriers due to practitioners. However, there are a few school social work practitioners who implement EBP interventions with the client system (El-Sayed, 2016, p. 10).

\section{Study Concepts:}

The researcher defined the operational concepts of the study as follows:

Evidence-based practice of social work: operationally defined as the process in which the skills, values, and knowledge related to evidence, and professional experience overlap, enable social workers to make appropriate decisions to address clients' problems, in order to achieve the use of treatment models capable of improving services provided to students in secondary schools.

Requirements of applying evidence-based practice: operationally defined as the scientific foundations (knowledge, skill, ethical and methodological) that make social workers able to find answers to questions based on clients' needs, identify the most available evidence to answer these questions, evaluate the quality of evidence obtained, apply the evidence, and evaluate the efficiency and effectiveness of this evidence.

Social Work in Secondary Schools: operationally defined as organized professional efforts that work to nurture the social growth of secondary schools' students with the aim of creating the most appropriate conditions for their growth according to their preferences and in accordance with the conditions and needs of the Egyptian society.

\section{Methodology}

Study Design: The current research is a descriptive study that aims to identify the requirements of applying evidence-based practice of social work in secondary schools. The study follows a social survey method. Following data collection, appropriate statistical analysis is carried out. The study population includes (3658) social workers in secondary schools in Egypt (CAPMAS, 2019). A sample consisting of 
348 school social workers was selected randomly (Johnson \& Christenson, 2008, P.242). It is chosen according to the following criteria: written approvals from the study participants and cooperation with the researcher in implementing the study. The data is collected throughout the academic year 2019/2020.

\section{Data Collection Procedure and Ethical Considerations:}

A survey with a cover letter explaining the purpose of the study is prepared. It also contains a written agreement from the study respondents. Approval is obtained from each of the social workers. Then, all participants are asked to complete a questionnaire. The data collection process has continued for about six months. Concerning the data collection procedures in secondary schools, participants receive electronic questionnaire by Google forms.

\section{Study Measures}

The measures used in this study are part of a questionnaire design implemented for Secondary school social workers. The questionnaire focuses on the requirements of EBP of social work in secondary schools, the barriers of using EBP, and the clarity of the concept of EBP for social workers. Four items are used to establish relevant demographics: gender, education level, years of experience, and training sessions. To capture the perceptions of requirements; 31 items are developed to assess knowledge requirements, 24 items to assess the value requirements, 18 items to assess the ethical requirements, and 25 items to assess the barriers of using EBP.

Response options are presented on a three-point Likert-type scale assessing agreement with the stem: $1=$ disagree, $2=$ neutral, $3=$ agree. Scores are recorded to clarify the responses to these questions to better reflect participants' perceptions. The final instrument is reviewed for content validity by 15 social work professors with expertise in this area in order to assure that the questionnaire content asks the appropriate questions of the potential research participants. Additionally, Cronbach's alpha is used to calculate the internal consistency of the measurement scale. From the statistical analysis, it can be concluded that the instrument is reliable as a score of 0.892 was obtained for the items.

\section{Data Analysis}

Data analyses are performed using SPSS, v.24. Descriptive statistical techniques are applied to clarify demographic characteristics of the study sample. Such techniques include the calculation of the frequencies and percentages (mean, and standard deviation) for each 
Likert-scale item. Lastly, the Spearman-Brown Prediction Formula and Cronbach's alpha are used to assess the reliability of the study tools and measure the strength of the tools' consistency.

\section{Results of the Study:}

Table (1): The demographic information of participants

\begin{tabular}{|c|c|c|c|}
\hline Items & Variable & $\overline{\mathrm{N}}$ & $\%$ \\
\hline \multirow{2}{*}{ Gender } & Male & 140 & 40.23 \\
\hline & Female & 208 & 59.77 \\
\hline \multirow{3}{*}{ Scientific qualification } & BSW & 152 & 43.68 \\
\hline & MSW & 1116 & 33.33 \\
\hline & PhD SW & 80 & 22.99 \\
\hline \multirow{3}{*}{ Experience } & 1-5 years & 17 & 4.89 \\
\hline & $6-10$ years & 314 & 90.2 \\
\hline & More than 10 years & 17 & 4.89 \\
\hline \multirow{2}{*}{ Training sessions } & Yes & 118 & 33.9 \\
\hline & 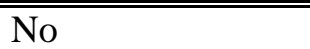 & 230 & 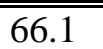 \\
\hline
\end{tabular}

Table (1) shows the demographic information of the participants. The study sample is characterized as follows:

- The percentage of gender representation: (40.23\%) for males and $(59.77 \%)$ for females;

- The scientific qualifications obtained by social workers:(43.68\%) had Bachelor of social work, (33.33\%) obtained Master of social work, $(22.99 \%)$ were granted Ph.D. of social work.

- The average of the participants' experience in the school field ranged between (6-10) years.

- The school social workers' responses concerning EBP training courses are diverse as (33.9\%) agreed that they participate in EBP training sessions.

Table (2): The clarity of the concept of EBP for secondary schools' social workers

\begin{tabular}{||l||l||l||l|l||l||l||}
\hline \multirow{2}{*}{$\begin{array}{l}\text { Is the concept EBP in the school } \\
\text { field clear? }\end{array}$} & Clear & \multicolumn{2}{l||}{ Not clear } & \multicolumn{2}{l|}{ Total } \\
\cline { 2 - 7 } & $\mathrm{N}$ & $\%$ & $\mathrm{~N}$ & $\%$ & $\mathrm{n}$ & $\%$ \\
\hline & 120 & 34.5 & 228 & 65.5 & 348 & 100 \\
\hline
\end{tabular}

The results of the table (2) confirmed that the concept of EBP is not clear for social workers in secondary schools in Egypt as the majority of these school social workers $(65.5 \%)$ answered "Not clear" to the question of how much they understand EBP. This may be partially due to the low number of EBP training courses attended by social workers. 


\begin{tabular}{|lc||}
\hline Egyptian Journal of Social Work (EJSW) & http://ejsw.journals.ekb.eg \\
ISSN: 2356-9204 & Vol 12, Issue 1, June 2021 \\
\hline
\end{tabular}

\section{Table (3): The requirements of applying EBP of social work in secondary schools.}

\begin{tabular}{||l||l||l||l||}
\hline \multicolumn{2}{|l||l||l||}{ M } & \multicolumn{2}{l||}{ R } \\
\hline \hline A) The knowledge requirements & 2.88 & 96 & 1 \\
\hline \hline Knowledge of the steps of EBP & 2.55 & 85 & 4 \\
\hline \hline $\begin{array}{l}\text { Knowledge of the use of information in the tasks } \\
\text { of scientific research and evaluation of practice }\end{array}$ & 2.55 & 85 & 4 \\
\hline \hline $\begin{array}{l}\text { Drawing on the results of studies and research } \\
\text { published in the consolidation of evidence }\end{array}$ & 2.55 & 85 & 4 \\
\hline \hline $\begin{array}{l}\text { Reference to global databases in the search for best } \\
\text { practices }\end{array}$ & 2.55 & 85 & 4 \\
\hline $\begin{array}{l}\text { Utilizing the expertise of specialists to activate } \\
\text { EBP in the school field }\end{array}$ & 2.82 & 94 & 3 \\
\hline \hline $\begin{array}{l}\text { Knowledge related to scientific research and its } \\
\text { steps }\end{array}$ & 2.46 & 82 & 5 \\
\hline \hline Knowledge of the knowledge of how to apply EBP & 2.46 & 82 & 5 \\
\hline \hline $\begin{array}{l}\text { Knowledge of knowledge associated with EBP } \\
\text { research methodology }\end{array}$ & 2.46 & 82 & 5 \\
\hline \hline $\begin{array}{l}\text { Use the latest scientific references to provide } \\
\text { knowledge associated with the methodology of } \\
\text { professional intervention }\end{array}$ & 2.46 & 82 & 4 \\
\hline \hline Identify the obstacles to EBP & 2.46 & 82 & 5 \\
\hline \hline $\begin{array}{l}\text { Understand and understand databases by extracting } \\
\text { evidence }\end{array}$ & 2.82 & 94 & 3 \\
\hline \hline $\begin{array}{l}\text { Acquisition of books interested in the methodology } \\
\text { of EBP }\end{array}$ & 2.82 & 94 & 3 \\
\hline \hline Knowledge related to how evidence is used & 2.37 & 79 & 6 \\
\hline \hline $\begin{array}{l}\text { Establish local databases by providing evidence in } \\
\text { the fields of the profession }\end{array}$ & 2.37 & 79 & 6 \\
\hline \hline $\begin{array}{l}\text { Knowledge of information and facts about the } \\
\text { methods of development of the school community } \\
\text { through research }\end{array}$ & 2.55 & 85 & 4 \\
\hline \hline Knowledge related to the use of the Internet & 2.55 & 85 & 4 \\
\hline \hline $\begin{array}{l}\text { Knowledge related to working with students } \\
\text { through the published research }\end{array}$ & 2.37 & 79 & 6 \\
\hline \hline Knowledge of what EBP is & 2.88 & 96 & 1 \\
\hline \hline Know how to use the computer & 2.82 & 94 & 3 \\
\hline \hline Knowledge of studies related to the field of school & 2.37 & 79 & 6 \\
\hline \hline Knowledge related to the steps of manual & 2.85 & 95 & 2 \\
\hline \hline
\end{tabular}




\begin{tabular}{|lr||}
\hline Egyptian Journal of Social Work (EJSW) & http://ejsw.journals.ekb.eg \\
ISSN: 2356-9204 & Vol 12, Issue 1, June 2021 \\
\hline \hline
\end{tabular}

\begin{tabular}{|c|c|c|c|}
\hline The requirements & $\overline{\mathrm{M}}$ & $\%$ & $\overline{\mathrm{R}}$ \\
\hline \multicolumn{4}{|l|}{ extraction } \\
\hline $\begin{array}{l}\text { Knowledge associated with criteria for selecting } \\
\text { appropriate evidence }\end{array}$ & 2.46 & 82 & 5 \\
\hline $\begin{array}{l}\text { Knowledge related to how to apply EBP in student } \\
\text { work }\end{array}$ & 2.88 & 96 & 1 \\
\hline $\begin{array}{l}\text { Identify the ways to design programs of care } \\
\text { provided to students based on proven programs }\end{array}$ & 2.82 & 94 & 3 \\
\hline Benefit from published studies and research & 2.46 & 82 & 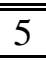 \\
\hline $\begin{array}{l}\text { Knowledge of databases for the extraction of the } \\
\text { manual }\end{array}$ & 2.55 & 85 & 4 \\
\hline Converting information needs into a question & 2.55 & 85 & 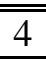 \\
\hline Awareness of information types \& sources & 2.37 & 79 & 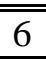 \\
\hline Knowledge of how to retrieve evidence & 2.37 & 79 & 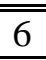 \\
\hline $\begin{array}{l}\text { Knowledge of the characteristics of the society in } \\
\text { which EBP is practiced }\end{array}$ & 2.85 & 95 & 2 \\
\hline $\begin{array}{l}\text { Integrating knowledge and theory and how to use } \\
\text { it in the process of EBP }\end{array}$ & 2.85 & 95 & 2 \\
\hline Total & 2.60 & 86.4 & \\
\hline \multicolumn{4}{|l|}{ B) The skill requirements } \\
\hline Skill of convert information into questions & 2.7 & 90 & 2 \\
\hline $\begin{array}{l}\text { Evaluate the results of professional intervention } \\
\text { using EBP. }\end{array}$ & 2.7 & 90 & 2 \\
\hline $\begin{array}{l}\text { The skill of employing evidence in professional } \\
\text { interventions with students }\end{array}$ & 2.7 & 90 & 2 \\
\hline "Ability to think critically of the evidence reached & 2.7 & 90 & 2 \\
\hline Ability to use the computer & 2.7 & 90 & 2 \\
\hline Ability to deal with different search engines & 2.61 & 87 & 3 \\
\hline $\begin{array}{l}\text { Has the ability to use the Internet in search of } \\
\text { evidence }\end{array}$ & 2.61 & 87 & 3 \\
\hline $\begin{array}{l}\text { Ability to know the quality of new evidence in the } \\
\text { school field }\end{array}$ & 2.61 & 87 & 3 \\
\hline $\begin{array}{l}\text { The skill of formulating questions related to the } \\
\text { manual }\end{array}$ & 2.55 & 85 & 4 \\
\hline $\begin{array}{l}\text { The skill of applying the guide in professional } \\
\text { intervention with students }\end{array}$ & 2.55 & 85 & 4 \\
\hline $\begin{array}{l}\text { The ability to select appropriate evidence in } \\
\text { intervention with students }\end{array}$ & 2.55 & 85 & 4 \\
\hline The skill of the team work & 2.55 & 85 & 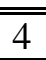 \\
\hline
\end{tabular}




\begin{tabular}{|lr||}
\hline Egyptian Journal of Social Work (EJSW) & http://ejsw.journals.ekb.eg \\
ISSN: 2356-9204 & Vol 12, Issue 1, June 2021 \\
\hline \hline
\end{tabular}

\begin{tabular}{|c|c|c|c|}
\hline The requirements & $\bar{M}$ & $\%$ & $\mathrm{R}$ \\
\hline The skill of formulating research hypotheses & 2.55 & 85 & 4 \\
\hline $\begin{array}{l}\text { The skill of dealing with international scientific } \\
\text { databases to extract evidence or sources of } \\
\text { evidence such as randomized controlled trials and } \\
\text { systematic reviews. }\end{array}$ & 2.52 & 84 & 5 \\
\hline Ability to use E-mail & 2.52 & 84 & 5 \\
\hline $\begin{array}{l}\begin{array}{l}\text { English language proficiency in dealing with } \\
\text { global scientific databases }\end{array} \\
\end{array}$ & 2.52 & 84 & 5 \\
\hline $\begin{array}{l}\text { Can identify the justification for selecting specific } \\
\text { evidence in a professional intervention }\end{array}$ & 2.52 & 84 & 5 \\
\hline $\begin{array}{l}\text { The skill of analyzing the results of scientific } \\
\text { research published in the field of school }\end{array}$ & 2.49 & 83 & 6 \\
\hline Ability to implement and use EBP. & 2.49 & 83 & 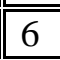 \\
\hline $\begin{array}{l}\text { Skills of employ the results of the calendar in the } \\
\text { development of professional work }\end{array}$ & 2.4 & 80 & 7 \\
\hline Ability to prioritize the evidence obtained & 2.4 & 80 & 7 \\
\hline $\begin{array}{l}\text { Ability to employ scientific research in EBP in the } \\
\text { school field }\end{array}$ & 2.4 & 80 & 7 \\
\hline $\begin{array}{l}\text { Skills of search the appropriate directory for each } \\
\text { case }\end{array}$ & 2.85 & 95 & 1 \\
\hline Ability to analyze and critique research evidence & 2.85 & 95 & 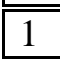 \\
\hline Total & 2.58 & 86 & \\
\hline \multicolumn{4}{|l|}{ C) The ethical requirements } \\
\hline $\begin{array}{l}\text { Taking into consideration the values, expectations } \\
\text { and circumstances of the clients during } \\
\text { professional intervention }\end{array}$ & 2.55 & 85 & 2 \\
\hline $\begin{array}{l}\begin{array}{l}\text { Commitment to continuous development of } \\
\text { performance }\end{array} \\
\end{array}$ & 2.4 & 80 & 4 \\
\hline $\begin{array}{l}\text { Commitment to and respect for the culture of } \\
\text { society }\end{array}$ & 2.49 & 83 & 3 \\
\hline Commitment to the ethics of the profession & 2.7 & 90 & 1 \\
\hline take approvals before Implementation on students & 2.4 & 80 & 4 \\
\hline $\begin{array}{l}\text { Commitment to the scientific secretariat with } \\
\text { regard to the application of the results of the } \\
\text { researches of professional intervention. }\end{array}$ & 2.49 & 83 & 3 \\
\hline $\begin{array}{l}\text { Commitment to the participation of clients in } \\
\text { decision-making }\end{array}$ & 2.4 & 80 & 4 \\
\hline Take care to criticize the evidence obtained. & 2.7 & 90 & 1 \\
\hline
\end{tabular}




\begin{tabular}{|lr||}
\hline Egyptian Journal of Social Work (EJSW) & http://ejsw.journals.ekb.eg \\
& Vol 12, Issue 1, June 2021 \\
\hline \hline
\end{tabular}

\begin{tabular}{|c|c|c|c|}
\hline The requirements & 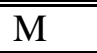 & $\%$ & $\mathrm{R}$ \\
\hline Commitment to the values of team work & 2.49 & 83 & 3 \\
\hline $\begin{array}{l}\text { Objectivity in the application, and non - bias for } \\
\text { certain quality of treatment when dealing with } \\
\text { students }\end{array}$ & 2.7 & 90 & 1 \\
\hline $\begin{array}{l}\text { Taking into account individual differences } \\
\text { between students. }\end{array}$ & 2.55 & 85 & 2 \\
\hline $\begin{array}{l}\text { taking into account the individual characteristics of } \\
\text { student }\end{array}$ & 2.7 & 90 & 1 \\
\hline $\begin{array}{l}\text { Commitment to the use of remedial methods } \\
\text { appropriate to the environment and culture of } \\
\text { students. }\end{array}$ & 2.4 & 80 & 4 \\
\hline $\begin{array}{l}\text { Taking into account the opinion of students when } \\
\text { providing any service }\end{array}$ & 2.55 & 85 & 2 \\
\hline $\begin{array}{l}\text { Commitment to confidentiality, in relation to } \\
\text { professional intervention with students. }\end{array}$ & 2.7 & 90 & 1 \\
\hline $\begin{array}{l}\text { Seeking to improve the care provided to students } \\
\text { through published research results }\end{array}$ & 2.49 & 83 & 3 \\
\hline $\begin{array}{l}\text { Cooperation with the school staff to improve the } \\
\text { services provided to students according to the } \\
\text { latest published studies }\end{array}$ & 2.55 & 85 & 2 \\
\hline $\begin{array}{l}\text { Keen to achieve the social and psychological } \\
\text { progress of students }\end{array}$ & 2.49 & 83 & 3 \\
\hline Total & 2.54 & 84 & \\
\hline
\end{tabular}

In order to identify the social workers' views on the requirements of EBP of social work in secondary schools, respondents are asked to select from the list of requirements that are distributed to them, where table (3) shows social workers' perceptions of the requirements of applying evidence-based practice of social work in secondary schools. Accordingly, the results of the study indicate that there are many requirements of EBP in school social work settings; the knowledge requirements $(86.74 \%)$, the skill requirements $(86 \%)$, the ethical requirement $(84 \%)$, (see Table 3 ). 
Table (4): the barriers of applying evidence-based practice of social work in secondary schools

\begin{tabular}{|c|c|c|c|}
\hline The barriers & M & $\%$ & $\mathrm{R}$ \\
\hline $\begin{array}{l}\text { Practitioner's inability to implement the steps of } \\
\text { practicing evidence-based social work }\end{array}$ & 2.85 & 95 & 1 \\
\hline Weakness of social workers' research skills & 2.7 & 90 & 2 \\
\hline Lack of skills to formulate questions for social workers & 2.55 & 85 & 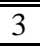 \\
\hline Lack of critical analysis skills among practitioners & 2.49 & 83 & 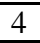 \\
\hline Lack of practitioners' computer and internet skills & 2.7 & 90 & 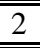 \\
\hline Lack of social workers' preparation in the field of EBP & 2.85 & 995 & 1 \\
\hline Lack of time for social workers & 2.49 & 83 & 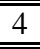 \\
\hline Large caseload in school. & 2.55 & 85 & 3 \\
\hline Limited appraisal skills for social workers. & 2.49 & 83 & 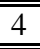 \\
\hline Difficulty in accessing scientific journals & 2.7 & 90 & 2 \\
\hline $\begin{array}{l}\text { Lack of evidences that support what is done in } \\
\text { occupational therapy }\end{array}$ & 2.85 & 95 & 1 \\
\hline Professional isolation of some social workers & 2.4 & 80 & 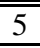 \\
\hline $\begin{array}{l}\text { Limited resources to support change to evidence-based } \\
\text { social work practice }\end{array}$ & 2.49 & 83 & 4 \\
\hline $\begin{array}{l}\text { Large size of published research in social work - } \\
\text { difficult to sift through }\end{array}$ & 2.4 & 80 & 5 \\
\hline $\begin{array}{l}\text { The use of research evidence is not a high priority for } \\
\text { social workers in school }\end{array}$ & 2.7 & 90 & 2 \\
\hline Habits dominant at schools & 2.85 & 95 & 1 \\
\hline $\begin{array}{l}\text { Benefits of evidence - based social work practice are } \\
\text { not clear }\end{array}$ & 2.4 & 80 & 5 \\
\hline $\begin{array}{l}\text { Limited support of social worker for continuing } \\
\text { education }\end{array}$ & 2.55 & 85 & 3 \\
\hline Lack of support from Professional supervisors & 2.49 & 83 & 4 \\
\hline Lack of support of school administration & 2.7 & 90 & 2 \\
\hline $\begin{array}{l}\text { Not receiving suitable learning at social work institutes } \\
\text { and colleges }\end{array}$ & 2.85 & 95 & 1 \\
\hline $\begin{array}{l}\text { Lack of guidance and support, generally, at Egyptian } \\
\text { schools }\end{array}$ & 2.85 & 95 & 1 \\
\hline $\begin{array}{l}\text { The implementation of EBP requires expensive } \\
\text { financial costs }\end{array}$ & 2.7 & 90 & 2 \\
\hline $\begin{array}{l}\text { The scarcity of Arab scientific researches that supports } \\
\text { the use of EBP in the school social work }\end{array}$ & 2.85 & 95 & 1 \\
\hline $\begin{array}{l}\text { Lack of technological capabilities within educational } \\
\text { institutions that support the use of EBP with clients }\end{array}$ & 2.55 & 85 & 3 \\
\hline Total & 2.64 & 88 & \\
\hline
\end{tabular}

The most outstanding barriers from the participants' point of view, as shown in table (4), is the practitioner's inability to implement the steps of social work evidence-based practice, lack of social 
workers' preparation in the field of EBP, lack of evidence that support what is done in occupational therapy, dominant habits at schools, lack of suitable learning, guidance and support at social work institutes and colleges and generally, at Egyptian schools. In addition, other barriers involve the scarcity of Arab scientific research that support the use of EBP in the school social work (95\%), lack of social workers' research skills, lack of computer and internet skills and the difficulty in accessing scientific journals. Moreover, the use of research evidence is not a high priority for social workers in school, lack of support of school administration, and the implementation of EBP requires expensive financial costs (90\%). (see table 4).

\section{Discussion}

This study aims to determine the requirements of applying evidence-based practice of social work in secondary schools. The results are discussed in view of the results of respondents' responses to the research questions:

The results show unclear concept of EBP for social workers in secondary schools. This is due to the low number of training courses received by social workers in EBP (Mustafa, 2018). There is a need to include EBP in the stages of social work education, as well as the preparation of the practitioner theoretically and practically, and intensive training courses for social workers in EBP (Zedan, et al, 2016).

Concerning the results of determining the knowledge requirements for the application of the EBP in the school social work settings, which emphasize its importance as the first requirements, they include:

- Following up the recent trends in the work of the school social worker, reviewing the research and periodicals for dealing with school problems and recognizing modern techniques in dealing with students' situations. (Mustafa, 2018);

- Identifying databases for the extraction of the criteria for selecting appropriate evidence, and the knowledge related to how to apply EBP in social work, benefit from published studies in social work (Ahmed, 2017);

- Knowledge related to the use of the internet, to scientific research and its steps, to how to employ evidence (Abdelaal, 2017);

- Knowledge of activities related to utilizing research, self-rated knowledge of research concepts and perceived knowledge of EBP and its individual steps (Buchanan et al, 2015). 
Accordingly, there is a need to strengthen the knowledge-based aspect of EBP in the social work at schools through continuous learning, intensive training courses, and EBP inclusion among social work curricula in the educational programs of the social work institutes and colleges in Egypt (Helal, 2017). It is important to provide ongoing education for social workers who do not have current knowledge about EBP and its importance in school care (Houser \& Oman, 2011). Concerning the results of determining the skill requirements of implementing the EBP in the school social work, which came in second place, they include:

- Ability to search for the suitable evidence for each case, to employ evidence in professional interventions with cases, in addition to the skills of analyzing results of published scientific research and extracting evidence from them, criticizing research evidence, selecting appropriate evidence in intervention with client and ability to formulate questions (Abdelaal, 2017);

- Ability to formulate research hypotheses, ability to deal with scientific databases to extract evidence using E-mail, English language proficiency, using computer skills (Ahmed, 2017);

- critical thinking skills, ability to browse the internet networks, and ability to implement professional interventions (Mustafa, 2018).

As a result, social workers in the school field are likely to lack skills of EBP, which is worrisome for the future of social work profession in Egypt. Consequently, students should be given the opportunity to learn the key skills essential to adopting EBP in professional interventions with clients (Helal, 2017), which requires more training courses to improve the skills of social workers in secondary schools, so that they can apply EBP in their field.

Concerning the results of determining the ethical requirements for applying the EBP in the school social work, they include:

- Social workers can rely on their ethics and accreditation standards to form a view of EBP to address obstacles implementing it, for example, the Code of Ethics (NASW, 1999) calls on social workers to benefit from the results practice and policy-related research, to respect guiding principles and to respect clients and empower them (Gambrill, 2007);

- Beneficence, avoiding harm, and maximizing autonomy and selfdetermination (Gambrill, 2006);

- Respecting values, expectations and circumstances of the clients during professional intervention, adhering to continuous development 
of professional performance, respecting the culture of society (Abdelaal, 2017),

- Conserving the values of teamwork, objectivity in the application EBP, taking into account individual differences between clients, the individual characteristics of cases, using remedial methods appropriate to the environment and culture of clients (Ahmed, 2017).

Concerning the barriers of using EBP in school social work settings in Egypt, they involve:

- The practice of social work in the field of school is restricted to the traditional practice centered on social casework, social group work, and community organization (Bahjat, 2015);

- Practitioners' preference to handle professional interventions with the stereotypical models they are accustomed to be used, so this traditional structure may hinder the incorporation of EBP, which leads to a social worker who is unable to meet clients' demands and perform professional practice effectively (Helal, 2013);

- Working hours for social workers are not enough because of large caseload in schools, limited appraisal skills for social workers, lack of evidence to support occupational therapy in social work and difficulty accessing scientific journals (Abdelaal, 2017),

- Low incomes of social work practitioners, inability of schools to contact supportive databases to find appropriate evidence, and unavailability of technological capabilities supporting use of EBP with students (Helal, 2017).

\section{Implications}

The results obtained from this study lead to the following recommendations:

a) The importance of strengthening the knowledge aspect of EBP for social workers in secondary schools;

b) The need to EBP inclusion in the educational programs of the social work institutes and colleges in Egypt;

c) The need to provide ongoing education for social workers who do not have current knowledge about EBP;

d) The need to more training courses to improve the skills of social workers in secondary schools, so that they can apply EBP in schools;

e) The need to obligate the ethical code of the social work profession in secondary schools;

f) The need to provide appropriate financial support for the application of EBP in secondary schools. 


\section{Limitations}

There are several limitations to this study. Firstly, this study relies on the perceptions of a limited sample of school social workers in Egypt. Future samples from different geographical regions may provide more robust results. Secondly, the study is limited with the specific description of skill, knowledge, and ethical requirements; it would be more valuable if the study went with predictive purposes. Additionally, the questionnaire is self-reported and does not capture the observed practices in respondent's agencies, related to EBP implementation. Accordingly, because the surveys are self-reported, participants may have given consistently high or low ratings. These may have biased results and served as sources of error and affect variance.

\section{Conclusion}

Social workers in secondary schools need to meet three basic requirements when trying to implement EBP. Practitioners in the sample of this study identified knowledge, skills, and ethics as requirements of applying EBP in school social work settings. Findings from this study may provide a base for research into how to effectively apply EBP in secondary schools. Further research is also needed to promote the impact of EBP in school social work settings. This study attempts to highlight the barriers in applying EBP in Egypt, and finally, there is a dire need to conduct regular continuing education programs in Egypt concerned with the use of EBP with practitioners and students.

\section{References}

Abdelaal, M. M. (2017). The requirements of applying evidence - based community practice in community organizing intervention research. Master thesis, Assuit University, Faculty of Social Work.

Ahmed, S. G. (2017). The requirements of using evidence-based practice in working with the individual cases in deposit institutions. Master thesis, Assuit University, Faculty of Social Work.

Albrithen, A. (2010). Scientific articles in social work. Oman, Jordan: Dar Al- Feker.

Barret, C. et al. (2008). Practice standards for school social workers. Australian Association of Social Workers (AASW).

Bahjat, S, M. (2015). Mechanisms of evidence-based professional practice in social work: a vision from the perspective of community organization. Journal Studies in Social Work And Human Sciences, Helwan University, Faculty of Social Work, N. 39, V.14. 
Berzin, S. C., \& O'Connor, S. (2010). Educating today's school social workers: are school social work courses responding to the changing context. Children \& Schools, V. 32, Issue 4, 1 October 2010, Pages 237-249, doi.org/10.1093/cs/32.4.237

Buchanan, H., Siegfried, N., Jelsma, J. (2015). Survey Instruments for Knowledge, Skills, Attitudes and Behaviour Related to Evidencebased Practice in Occupational Therapy: A Systematic Review. Occup Ther Int. Jun;23(2):59-90. doi: 10.1002/oti.1398.Epub 2015 Jul 3.

Central Agency for Public Mobilization and Statistics (CAPMAS). (2019). Statistical year book. Arab Republic of Egypt, issue No. (110).

Cynthia, F. \& Laura, H.(2004). Into the Schools with Evidence-Based Practices. Children \& Schools, V. 26, Issue 2, 1 April, Pages 6770, doi.org/10.1093/cs/26.2.67.

Eliasson, B. (2014). Social Work Approaching Evidence-Based Practice: Rethinking Social Work. PhD thesis, Luleå University of Technology retrieved from http://urn.kb.se/resolve?urn=urn:nbn:se:ltu:diva-18343.

El-Sayed, A. (2016). Evidence-based- social work practice in deal with family disputes cases. Master thesis, Fayoum University, Faculty of Social Work.

El-Nagem, M. (2009). Evidence-based Practice in Social Work. Journal of King Saud University, Riyadh, V.21. N.2.

Evidence-Based Practice. (2018). https://www.socialworkers.org/News/Research-Data/Social-WorkPolicy-Research/Evidence-Based-Practice

Gibbs, L. (2003). Evidence-based practice for the helping professions: A practical guide with integrated multimedia. Pacific Grove, CA: Brooks/ Cole an Imprint of Wadsworth Publishers.

Hapeep, G. \& Hana, M. (2011). Contemporary social work. Alexandria: Modern University Office.

Helal, A. (2013). The barriers facing practitioners when applying evidencebased practice at addiction institutions in Egyptian society. Paper presented at 7th International Conference, School of Social Work, the University of Southern California, Los Angeles.

Helal, A. (2017). Evidence-based practice in Arab societies. Encyclopedia of Social Work, NASW Press and Oxford University Press, 10.1093/acrefore/9780199975839.013.1269

Houser, J. \& Oman, K. (2011). Evidence-Based Practice: An Implementation Guide for Healthcare Organizations. Jones \& Bartlett Learning.

Howard, M. O. \& Jenson, J. M. (2013). Evidence-based practice. Encyclopedia of Social Work. NASW Press and Oxford University Press, https://: 10.1093/acrefore/9780199975839.013.137.

Gambrill, E. (2006). Evidence-based practice and policy: choices ahead. Research on Social Work Practice. N.16. 338-357. $10.1177 / 1049731505284205$.

Gambrill, E. (2007). Views of evidence-based practice: Social workers' code of ethics and accreditation standards as guides for choice. Journal of Social Work Education, N.43, 447-462. 
Khalil, N. \& Farhan, H. (2014). Evidence based practice in social work contemporary strategy and integrative approach. Riyadh: Al Rasheed Bookstore.

Johnson, R. \& Christensen, L. (2008). Educational Research: Quantitative, Qualitative, and Mixed Approaches. $3^{\text {rd }} \mathrm{Ed}$, Lose Angeles, Sage Publications, P242.

kamar, E. \& Mabrouk, S. (2012). Introduction to social work. Cairo: Dar Al-Fikr.

Mustafa, M. (2018). A suggested vision to use the social workers of evidence - based practice with cases of addiction. Master thesis, Aswan University, Faculty of Social Work.

National Association of Social Workers. (1999). Code of ethics. Silver Spring, MD.

Nichols, D. (2018). Evidence-based practice for social work. Retrieved from https://guides.lib.umich.edu/EBP-Research.

Powers. J., Natasha, K., Gary, L. (2011). Supporting evidence-based practice in schools with an online database of best practices. children \& schools, V. 33, Issue 2, 1 April 2011, Pages 119-128, doi.org/10.1093/cs/33.2.119

Reid, D. (2018). Evidence-based practice in social work. Retrieved from https://study.com/academy/lesson/evidence-based-practice-in-socialwork.html

Saad, L.(2014). Evidence- based practice in social work and the readiness of faculty members to teach such trend. Journal of Social Affairs V.31, Issue 122, pp.135-182.

Sohlberg, P. \& Sohlberg, B. (2013). Knowledge shapes: Science theory and research method (Swedish) Stockholm, Liber.

Suleiman, M. \& Yusuf's, F. (2020). the requirements of using the practice based on evidence as one of the contemporary trends in developing the professional practice of community organization method in institutions for the mentally handicapped. Journal Studies in Social Work And Human Sciences, Helwan University, Faculty of Social Work, N. 50, V.1.

Tawfiq, M. (1986). School Social work. Cairo: Anglo-Egyptian.

Teasley, M. (2016). Related services personnel and evidence-based practice: past and present challenges. children \& schools, V.38, Issue 1, 1 January 2016, Pages 5-8, doi.org/10.1093/cs/cdv039.

Thyer, B. (2006). What is evidence-based practice?. in: Roberts, Albert, R. \& Yeager, Kenneth, R. (eds.). Foundations of Evidence-Based Social Work Practice. Oxford University Press.

Zedan, A., Nasr, A., Helal, A. (2016). Evidence-based practice with individuals and families. Alexandria: Modern Office University. 
